\title{
Free Radicals, Antioxidants and Disease
}

Neeti Sharma*

Symbiosis School of Biomedical Sciences, Pune, Maharashtra, India

"Corresponding author: Neeti Sharma, Symbiosis School of Biomedical Sciences, Pune, Maharashtra, India, Tel: 09764435566, E-mail: neetimohan27@gmail.com

Received date: July 24, 2014 Accepted date: September 27, 2014, Published date: October 4, 2014

Copyright: (C) 2014 Neeti Sharma. This is an open-access article distributed under the terms of the Creative Commons Attribution License, which permits unrestricted use, distribution, and reproduction in any medium, provided the original author and source are credited.

\begin{abstract}
Living cells continually generate free radicals or reactive oxygen species (ROS) through the respiratory chain during energetic metabolism. ROS can either be harmful or play important physiological roles in our body. Besides being produced during normal cell metabolism there are numerous exogenous factors, such as irradiation by UV light, X-rays, gamma-rays, and atmospheric pollutants which may lead to generation of ROS. Human body has various intrinsic mechanisms to counteract oxidative stress by producing antioxidants, or through externally derived foods and/or supplements. However whenever there is excess of free radicals their accumulation in the body generates a phenomenon called oxidative stress. As we age, this oxidative and/or nitrosative damages elicit a number of late-onset diseases after ROS/RNS accumulate to certain levels. The ROS/RNS-mediated late-onset diseases can occur in any system of the body and may lead to clinical conditions such as cancer, arthritis arteriosclerosis, and neurodegenerative diseases. Oxidative stress is marked with expression of specific biomarkers whose specificity towards the various disease condition needs validation. In this review, we summarize the source, balance, maintenance and physiological functions of ROS, and its toxic mechanisms underlying a number of diseases and also the biomarkers implicated in selected human diseases.
\end{abstract}

Keywords Free radicals; Antioxidants; Biomarkers; Cancer; Neurodegenerative disorders

\section{Introduction}

Oxidative stress is defined as a disturbance in the equilibrium between free radicals (FR), reactive oxygen species (ROS) and the endogenous defense mechanisms [1]. It is the disturbance in the balance between oxidant-antioxidant states which favours the production of oxidant species [2]. Human body requires both oxidant and antioxidant species for normal metabolism, signal transduction and regulation of cellular functions. Therefore, each cell maintains a condition of homeostasis between the oxidant and antioxidant species $[3,4]$. Oxidative stress may lead to injury to all the important cellular components like proteins, DNA and membrane lipids, which can cause cell death. Oxidative stress has also implicated in various physiological and pathological processes, including DNA damage, proliferation, cell adhesion, and survival which has been validated by several experimental and clinical data in large number of pathological states as well as aging (Figure 1) [2,3].

The broad definition of the ROS is oxygen-containing, reactive chemical species. Up to $1-3 \%$ of the pulmonary intake of oxygen by humans is converted into ROS [5]. But it has to be emphasized that ROS and RNS are both produced in a well regulated manner to help maintain homeostasis at the cellular level in the normal healthy tissues and play an important role as signaling molecules. Most cells can produce superoxide $\left(\mathrm{O}_{2} \bullet-\right)$, hydrogen peroxide $\left(\mathrm{H}_{2} \mathrm{O}_{2}\right)$ and nitric oxide [NO] when required. Free radicals have several beneficial roles which can be enumerated as:

1. Generation of ATP (universal energy currency) from ADP in the mitochondria: oxidative phosphorylation

2. Detoxification of xenobiotics by Cytochrome $\mathrm{P}_{450}$ (oxidizing enzymes)

\section{Apoptosis of effete or defective cells}

4. Killing of micro-organisms and cancer cells by macrophages and cytotoxic lymphocytes

5. Oxygenases (eg. COX: cyclo-oxygenases, LOX: lipoxygenase) for the generation of prostaglandins and leukotrienes, which have many regulatory functions.

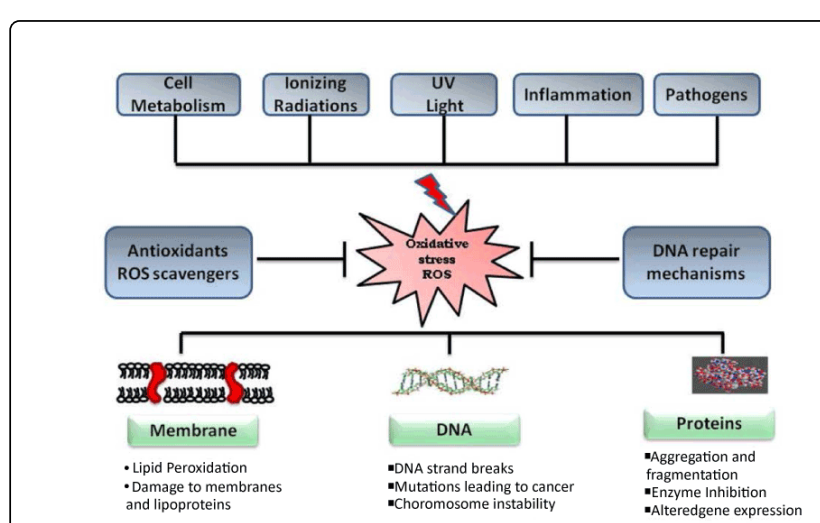

Figure 1: Oxidative Stress, disease and aging - Possible effects of Oxidative Stress

Besides it has also been demonstrated earlier that ROS such as $\mathrm{O}_{2}$ and $\mathrm{H}_{2} \mathrm{O}_{2}$ may act as second messengers and thus can regulate cellular function [4].

Reactive oxygen species (ROS) include superoxide, hydroperoxyl, hydroxyl, alkylperoxyl, alkoxyl, carbonate and carbondioxide radicals, while hydrogen peroxide and ozone represent non-radical species (Table 1) $[3,5,6]$. Nitrogen reactive species (RNS) can be divided into radicals and non-radicals as well (Table 1). Various studies have 
Page 2 of 6

demonstrated the role of reactive oxygen species in many degenerative diseases, such as atherosclerosis, cancers, stroke, trauma, asthma, heart attack, hyperoxia, arthritis, age pigments, cataract genesis, retinal damage, dermatitis, liver injury, hepatitis, and periodontis (Figure 2) $[5,6]$.

\begin{tabular}{|c|c|c|c|}
\hline \multicolumn{2}{|c|}{ Reactive Oxygen Species } & \multicolumn{2}{|c|}{ Reactive Nitrogen Species } \\
\hline Free Radicals & $\begin{array}{l}\text { Other } \\
\text { Substances }\end{array}$ & Free Radicals & Other Substances \\
\hline $\begin{array}{l}\text { Superoxide anion } \\
\text { radical } \mathrm{O}_{2^{\bullet-}}\end{array}$ & $\begin{array}{l}\text { Hydrogen } \\
\text { peroxide } \mathrm{H}_{2} \mathrm{O}_{2}\end{array}$ & $\begin{array}{l}\text { Nitric oxide } \\
\text { radical NO. }\end{array}$ & $\begin{array}{l}\text { Peroxynitrite ONOO } \\
\text { - }\end{array}$ \\
\hline $\begin{array}{l}\text { Hydroxyl radical } \\
\text { HO- }\end{array}$ & $\begin{array}{l}\text { Hypochlorous } \\
\text { acid } \mathrm{HOCl}\end{array}$ & $\begin{array}{l}\text { Nitric dioxide } \\
\text { radical } \mathrm{NO}_{2}\end{array}$ & Nitrites $\mathrm{NO}_{2}-$ \\
\hline Alkoxyl radical RO. & Ozone $\mathrm{O}_{3}$ & & Nitrates $\mathrm{NO}_{3}-$ \\
\hline $\begin{array}{l}\text { Peroxyl radical } \\
\text { ROO• }\end{array}$ & $\begin{array}{l}\text { Singlet oxygen } \\
1 \mathrm{O}_{2}\end{array}$ & & Nitrosyl NO+ \\
\hline
\end{tabular}

Table 1: Summary of reactive oxygen and nitrogen species [5,6]

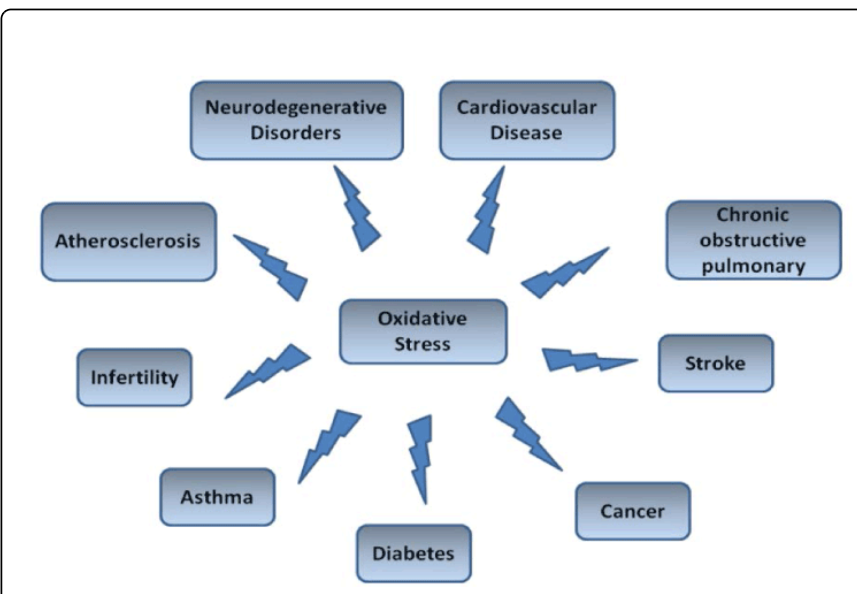

Figure 2: Oxidative stress-induced diseases in humans

\section{Defence System against Free Radicals}

Human body has natural antioxidant defence mechanism to counteract the FR produced which when present at very low concentrations compared with those of an oxidizable substrate, significantly delays or prevents oxidation of that substrate" [7]. The word oxidizable substrate includes almost everything (except $\mathrm{H} 2 \mathrm{O}$ ) found in foods such as oil and fat [8]; in living tissues it includes carbohydrates, lipids, proteins, and DNA [7]. There are two major types of antioxidants:

- Synthetic antioxidants: which include the phenolic compounds such as butylated hydroxyanisol (BHA), butylated hydroxytoluene (BHT), propyl gallate (PG) and tertiary butyl hydroquinone (TBHQ) which are largely used in the food industries to control the oxidation and maintain the food quality [9].

- Natural antioxidants: are the ascorbates, ascorbic acid (Vitamin C), tocopherols, $\boldsymbol{\alpha}$-tocopherol (Vitamin E), flavonoids (Vitamin P), carotenoids and phenolic acids.
Antioxidants are able to neutralize free radicals at the levels of prevention, interception as well as repair. Antioxidants can the stop the formation of ROS for e.g. superoxide dismutase (SOD) catalyses the dismutation of superoxide to $\mathrm{H}_{2} \mathrm{O}_{2}$ and catalase breaks it down to water $[10,11]$. Interception of free radicals is mainly by radical scavenging. At the repair and reconstitution level, mainly repair enzymes are involved [10-12] which neutralise the free radicals.

\section{Oxidative Damage to DNA, Lipids and Proteins}

The concept of Oxidative stress as first elaborated by Sies et al, 1986 [13] is the ineffective management of free radicals such as ROS and RNS by natural antioxidant defence mechanism thus describing the relation between free radicals and disease (Figure 2). Free radicals manily attack the cellular components viz. lipids, carbohydrates, proteins and DNA (Figure 1)

\section{Effect on lipids}

Lipid components of membrane undergo peroxidation as a result of action of free radicals. During Lipid peroxidation (LP) a large number of toxic by products are also formed that behave as 'second messengers'. The damage caused by LP is highly detrimental to the functioning of the cell [14]. Some of the products of LP such as malondialdehyde (MDA), 4- hydroxynonenal (4-HNE), various 2alkenals and Isoprostanes are of toxicological interest [14].

\section{Effect on carbohydrates}

Carbohydrates are attacked by free radicals such as $\bullet \mathrm{OH}$ which randomly abstracts a hydrogen atom from one of the carbon atoms, producing a carbon-centered radical. This phenomenon brings about chain breaks in molecules like hyaluronic acid. Additionally oxyradicals produced as a result of activation of neutrophils during inflammation in the synovial fluid surrounding joints, lead to rheumatoid arthritis.

\section{Effect on proteins}

Free radicals can cause direct damage to proteins which can directly interfere with enzyme activity and the function of structural proteins. Oxidation of proteins by ROS/RNS leads to production of stable as well as reactive products such as protein hydroperoxides that can further generate additional free radicals particularly upon interaction with transition metal ions. Mostly these oxidised forms of proteins are rapidly removed however their accumulation over a period of time can contribute to the damage associated with ageing as well as various diseases. Lipofuscin, an aggregate of peroxidized lipids and proteins accumulates in lysosomes of aged cells and brain cells of patients with Alzheimer's disease [15].

\section{Effect on DNA}

Free radical attack causes several types of alterations in the DNA such as fragmentation of DNA which in turn causes activation of the poly (ADP-ribose) synthetase enzyme. This splits $\mathrm{NAD}^{+}$to aid the repair of DNA. In case of excessive damage $\mathrm{NAD}^{+}$levels may become completely depleted leading to cell death which may be by necrosis or apoptosis depending on the type of cellular damage. Damage of cell membrane or an organelle by free radicals makes it vulnerable which may put the entire cell at risk. 
Page 3 of 6

\begin{tabular}{|l|l|}
\hline Mechanism & References \\
\hline DNA strand breaks & {$[21]$} \\
\hline $\begin{array}{l}\text { Formation of DNA adducts (due to covalent } \\
\text { binding ) }\end{array}$ & {$[21]$} \\
\hline Formation of DNA-protein cross-links & {$[21,22]$} \\
\hline Formation of DNA interstrand cross-links & {$[21]$} \\
\hline Activation of oncogenes & {$[23]$} \\
\hline Inactivation of tumour suppressor genes & {$[23]$} \\
\hline DNA base modification and/or destruction & {$[21,24]$} \\
\hline
\end{tabular}

Table 2: Possible mechanisms behind the induction of mutagenesis and carcinogenesis

\section{Oxidative Stress and Disease}

Attack of free radicals on the critical cellular components such as lipids carbohydrates, proteins and DNA have been implicated in various pathological conditions such as cardiovascular disease, cancer, neurological disorders, diabetes, ischemia/reperfusion, other diseases and ageing (Figure 2) [16-19].

These diseases can be categorized into two groups: (i) the first group involves diseases characterized by pro-oxidants shifting the thiol/disulphide redox state and impairing glucose tolerance-the socalled "mitochondrial oxidative stress" conditions (cancer and diabetes mellitus); (ii) the second group involves disease characterised by "inflammatory oxidative conditions" and enhanced activity of either $\mathrm{NAD}[\mathrm{P}] \mathrm{H}$ oxidase (leading to atherosclerosis and chronic inflammation) or xanthine oxidase-induced formation of ROS (implicated in ischemia and reperfusion injury). The process of ageing is largely due to the damaging consequence of free radical action (lipid peroxidation, DNA damage, protein oxidation).

Association of oxidative/ nitrosative stress and acute and chronic diseases have been shown by presence of validated biomarkers of oxidative stress $[16,20]$.

\section{Oxidative stress and cancer}

Cancer development in humans involves a complex process both at the cellular and molecular levels which is mediated by various endogenous and exogenous stimuli. Reactive species can induce mutagenesis via plenty of possible mechanisms [21-24] (Table 2). Besides carcinogens, radiations can bring about cancer initiation and promotion as a result of free-radical oxidation which is largely in the form of strand breaks in DNA. DNA strand breaks can be both single and double stranded. The breaks are generally repaired, can result in mutations that are heritable change in the DNA which can cause cancer in somatic cells or malformations in the germ cells. Free radicals involvement with tumor suppressor genes and protooncogenes indicate their involvement in the development of different human cancers [25]. Additionally lipid peroxidation which plays a key role in controlling cell division, its end product

Malondialdehyde (MDA) due to its high cytotoxic and inhibitory action on protective enzymes further acts as a tumor promoter or a cocarcinogenic agent. This has been shown in some type of cancers such as breast cancer [26]. Besides this oxidative stress may lead to activation of vascular endothelial growth factor and may induce angiogenesis which may further enhance malignancy [27-29].

\section{Oxidative stress and cardiovascular diseases}

Reactive oxygen species (ROS) function as signaling molecules regulating an array of processes in the cardiovascular system and contribute to a large extent in the maintenance of cardiovascular homeostasis [30]. Oxygen free radicals have been reported to play an important role in the pathogenesis of a number of cardiovascular diseases (CVDs) such as atherosclerosis, ischemia, hypertension, cardiomyopathy, cardiac hypertrophy and congestive heart failure by both in vivo and in vitro studies [31-35]. Potential sources of free radicals during ischemia and reperfusion have been identified in myocytes, vascular endothelium, and leukocytes. Injury to processes involved in regulation of the intracellular $\mathrm{Ca}^{2+}$ concentration may be a common mechanism underlying both free radical- induced and reperfusion abnormalities [36].

\section{Oxidative stress and neurodegenerative diseases}

Oxidative stress and free radical generation catalyzed by redox metals have been shown to play pivotal role in regulating redox reactions in vivo contributing RNS and ROS production which are the, main culprits in neurodegeneration [37]. Mitochondrial (Mt) dysfunctions, excitotoxicity and finally apoptosis are evident causes for neurodegenerative diseases such as Parkinson's disease (PD), Alzheimer's disease (AD), Multiple Sclerosis (MS) and Amyolotrophic lateral sclerosis (ALS). Mitochondrial dysfunction includes respiratory chain dysfunction and oxidative stress, reduced ATP production, calcium dysregulation, mitochondrial permeability transition pore opening, peturbation in mitochondrial dynamics, and deregulated mitochondrial clearance [38]. The production of $B$-amyloid, a toxic peptide often found in Alzheimer's patients' brain, is due to oxidative stress and plays an important role in the neurodegenerative processes [39]. AD brains also show evidence of ROS mediated-injury; there is an increase in levels of malondyaldehyde and 4-hydroxynonenal in brain and cerebrospinal fluid of $\mathrm{AD}$ patients compared to controls [40].

In Parkinson's disease the protein alpha-synuclein ( $\alpha$ Syn) binds to ubiquitin and forms proteinaceous cytoplasmic inclusions named Lewy bodies. Over accumulation and post translational modification of aSyn results in death of dopaminergic neurons [41-42]. Besides this increased lipid peroxidation, as well as oxidative DNA and protein damage is observed in substantia nigra [the brain area] that plays a major role in the development of Parkinson's disease [43-45].

In Huntington's disease the mutant huntingtin protein $(\mathrm{mHtt})$ aggregates and damage the retrograde transport of important molecules such as BDNF. This damage in transport occurs as a result of damaged molecular motors and microtubules [46] which causes pathological changes and disease symptoms. Additionally altered mitochondrial energy metabolism raises the production of free radicals thus resulting in severe neuronal trauma in Huntington's disease [47].

In ALS, motor neurons develop proteinaceous inclusions in their cell bodies and axons prior to their destruction. These inclusions generally contain ubiquitin, and often incorporate one of the ALSassociated proteins such as SOD1, TAR DNA binding protein (TDP-43, or TARDBP) or FUS. Protein degradation pathways play a crucial role in removing misfolded proteins thus preventing protein 
Page 4 of 6

aggregation. Accumulation of ALS-specific proteinaceous inclusions may be partly due to defects in protein degradation [48]. Evidences from post-mortem tissues from ALS patients have revealed that oxidative stress is the main causative factor responsible for accumulation of oxidative damage to lipids, proteins, and DNA thus suggesting a direct role in ALS progression [47,49,50]. Other disorders associated with oxidative stress and oxidative damage

Cardiovascular, neurodegenerative and oncological diseases are likely to be the most studied pathological conditions associated with oxidative stress. Since oxidation occur in all metabolically active, living cells, and therefore oxidative stress is associated with many other common disorders and conditions (Figure 1). The mechanisms behind the development and progression of such conditions are diverse for e.g. lungs, eyes and skin are naturally exposed to relatively high amounts of oxygen as well as to air pollutants which makes them vulnerable to oxidative damage. Heavy metals such as cadmium increase the generation of reactive oxygen species which promotes cell death [51]. However, the deficiency in exogenous antioxidant defence also plays an important part and can cause problems with ocular tissues [52,53].

\section{Biomarkers}

Several biomarkers have been reported as indicators of oxidative stress which include oxidation products of lipid, DNA and protein [16, 54-79] (Table 3). These biomarkers indicate the exposure of various antioxidant protective mechanisms to various oxidants in vivo [50]. Increase in oxidative stress in various pathologic conditions have suggested the use of specific biomarkers for the development of new diagnostic, therapeutic, and preventive strategies for delaying the development of complications such as cancer, atherosclerosis and coronary artery and neurodegenerative diseases.

\section{Concluding Remarks and Future Perspective}

Oxidative stress has been implicated in the etiology of several chronic and degenerative diseases [80,81]. Pathological effects of ROS are dealt by human body by utilizing the endogenous antioxidant system (e.g. enzymes such as superoxide dismutase), and by the consumption of antioxidants in the diet (e.g. flavonoids). Insufficient antioxidant levels may accelerate the aging process and some of the diseases associated with it.

The dependence of disease severity by an imbalance between oxidants and natural defenses suggests that antioxidant therapy represents a promising avenue for treatment. However successful development of effective antioxidant therapies still remains a key goal. Many novel approaches have been made and significant findings have come to light in the last few years. The most recent is redox proteomics which is a powerful tool to study redox regulation and signaling which involves global overview of the cellular redox state [82]. The molecular signatures of these short lived ROS/RNS molecules imprinted on lipids and proteins bring about positive oxidative stress, including redox signaling and activation of transcriptional factors [82]. Analysis of the cellular redox state will not only unveil the targets of reactive oxygen and nitrogen species but can also be instrumental in giving valuable insights to counteract oxidative stress. Additionally identification of novel biomarkers specific for disease states arising as a result of oxidative stress will be invaluable in providing information on possible mechanisms of diseases and new potential ways of prevention and treatment.

\begin{tabular}{|c|c|c|}
\hline Type of Biomarker & Disease & References \\
\hline $\begin{array}{l}\text { Ferric reducing ability of } \\
\text { plasma }\end{array}$ & $\begin{array}{l}\text { Cardiovascular } \\
\text { Diseases }\end{array}$ & [55] \\
\hline Carbonyls & $\begin{array}{l}\mathrm{AD}, \quad \text { Asthma,PD, } \\
\text { Diabetes } \\
\text { Cardiovascular } \\
\text { Diseases }\end{array}$ & {$[16,56,75,76]$} \\
\hline \multicolumn{3}{|l|}{ Lipid Peroxidation } \\
\hline Malondialdehyde & $\begin{array}{l}\text { AD, Asthma, } \\
\text { Atherosclerosis, } \\
\text { Cardiovascular } \\
\text { Diseases }\end{array}$ & {$[57,71,72]$} \\
\hline F2-isoprostane & $\begin{array}{l}\text { AD, Asthma, } \\
\text { Atherosclerosis, } \\
\text { Cardiovascular } \\
\text { Diseases, Diabetes, } \\
\text { Hypertension }\end{array}$ & {$[58,73,74]$} \\
\hline 4-Hydroxynonenal & $\begin{array}{l}\text { AD, } \\
\text { Atherosclerosis, } \\
\text { Cardiovascular } \\
\text { Diseases }\end{array}$ & {$[16,76]$} \\
\hline \multicolumn{3}{|l|}{ Plasma vitamins } \\
\hline Vitamin C & $\begin{array}{l}\text { Cardiovascular } \\
\text { Diseases }\end{array}$ & [59] \\
\hline Vitamin $\mathrm{E}$ & $\begin{array}{l}\text { Cardiovascular } \\
\text { Diseases }\end{array}$ & [60] \\
\hline \multicolumn{3}{|l|}{ Antioxidant enzymes } \\
\hline Superoxide dismutase & $\begin{array}{l}\text { Cardiovascular } \\
\text { Diseases }\end{array}$ & [61] \\
\hline Catalase & $\begin{array}{l}\text { Cardiovascular } \\
\text { Diseases }\end{array}$ & [62] \\
\hline Glutathione peroxidase & $\begin{array}{l}\text { Cardiovascular } \\
\text { Diseases }\end{array}$ & [63] \\
\hline $\begin{array}{l}\text { GSH/GSSG ratio in } \\
\text { erythrocyte }\end{array}$ & $\begin{array}{l}\text { AD, Asthma, } \\
\text { Atherosclerosis, } \\
\text { Cardiovascular } \\
\text { Diseases, Diabetes, } \\
\text { PD }\end{array}$ & {$[64,77,78]$} \\
\hline \multicolumn{3}{|l|}{ Prooxidant enzymes } \\
\hline Xanthine oxidase & $\begin{array}{l}\text { Cardiovascular } \\
\text { Diseases }\end{array}$ & [65] \\
\hline NADPH oxidase & $\begin{array}{l}\text { Cardiovascular } \\
\text { Diseases }\end{array}$ & [66] \\
\hline \multicolumn{3}{|l|}{ Others } \\
\hline $\begin{array}{l}\text { Endothelial } \\
\text { microparticles }\end{array}$ & $\begin{array}{l}\text { Cardiovascular } \\
\text { Diseases }\end{array}$ & [67] \\
\hline $\begin{array}{l}\text { Endothelial progenitor } \\
\text { cells }\end{array}$ & $\begin{array}{l}\text { Cardiovascular } \\
\text { Diseases }\end{array}$ & {$[68,79]$} \\
\hline $\begin{array}{l}\text { Ischemia } \quad \text { modified } \\
\text { albumin }\end{array}$ & $\begin{array}{l}\text { Cardiovascular } \\
\text { Diseases }\end{array}$ & [69] \\
\hline
\end{tabular}

Table 3: Biomarkers of oxidative stress 


\section{References}

1. McCord JM (2000) The evolution of free radicals and oxidative stress Am J Med 108: 652-659.

2. Harman D (1956) Aging: a theory based on free radical and radiation chemistry. J Gerontol 11: 298-300

3. Halliwell B (1996) Free radicals, proteins and DNA: oxidative damage versus redox regulation. Biochem Soc Trans 24: 1023-1027.

4. Halliwell B (1990) How to characterize a biological antioxidant. Free Radic Res Commun 9: 1-32.

5. Forman HJ, Fukuto JM, Torres M (2004) Redox signaling: thiol chemistry defines which reactive oxygen and nitrogen species can act as second messengers. Am J Physiol Cell Physiol 287: C246-256.

6. Packer L, Weber SU, Rimbach G (2001) Molecular aspects of alphatocotrienol antioxidant action and cell signalling. J Nutr 131: 369S-73S

7. Madeo J, Elsayad C (2013) The Role of Oxidative Stress in Alzheimer's Disease. J Alzheimers Dis Parkinsonism 3: 1-5.

8. Frankel EN, Meyer AS (2000) The problems of using one-dimensional methods to evaluate multifunctional food and biological antioxidants. J. Sci. Food agric 80: 1925-1941.

9. Tsuda H, Uehara N, Iwahori Y, Asamoto M, Iigo M, et al. (1994) Chemopreventive effects of beta-carotene, alpha-tocopherol and five naturally occurring antioxidants on initiation of hepatocarcinogenesis by 2-amino-3-methylimidazo[4,5-f] quinoline in the rat. Jpn J Cancer Res 85: 1214-1219.

10. Sies H (1996) (ed.) Antioxidants in Disease, Mechanisms and Therapy, Academic Press, New York, NY, USA.

11. Cadenas E and Packer L (1996) (eds) Hand Book of Antioxidants. Plenum Publishers, New York.

12. Halliwell B (1987) Free radicals and metal ions in health and disease. Proc Nutr Soc 46: 13-26.

13. Sies H (1997) Oxidative stress: oxidants and antioxidants. Exp Physiol 82: 291-295.

14. Devasagayam TP1, Boloor KK, Ramasarma T (2003) Methods for estimating lipid peroxidation: an analysis of merits and demerits. Indian J Biochem Biophys 40: 300-308.

15. Stadtman ER (1992) Protein oxidation and aging. Science 257: 1220-1224.

16. Dalle-Donne I, Rossi R, Colombo R, Giustarini D, Milzani A (2006) Biomarkers of oxidative damage in human disease. Clin Chem 52 601-623.

17. Dhalla NS, Temsah RM, Netticadan T (2000) Role of oxidative stress in cardiovascular diseases. J Hypertens 18: 655-673.

18. Jenner P (2003) Oxidative stress in Parkinson's disease. Ann Neurol 53 Suppl 3: S26-36.

19. Sayre LM, Smith MA, Perry G (2001) Chemistry and biochemistry of oxidative stress in neurodegenerative disease. Curr Med Chem 8: 721-738.

20. Dalle-Donne I, Scaloni A, Giustarini D, Cavarra E, Tell G, et al. (2005) Proteins as biomarkers of oxidative/nitrosative stress in diseases: the contribution of redox proteomics. Mass Spectrom Rev 24: 55-99.

21. Hazlewood C, Davies MJ (1996) Benzoyl peroxide-induced damage to DNA and its components: direct evidence for the generation of base adducts, sugar radicals, and strand breaks. Arch Biochem Biophys 332: 79-91.

22. Meffert R, Dose K, Rathgeber G, Schäfer HJ (2001) Ultraviolet crosslinking of DNA-protein complexes via 8-azidoadenine. Methods Mol Biol 148: 323-335.

23. Plaine HL (1955) The Effect of Oxygen and of Hydrogen Peroxide on the Action of a Specific Gene and on Tumor Induction in Drosophila Melanogaster. Genetics 40: 268-280.

24. Marnett LJ (2000) Oxyradicals and DNA damage. Carcinogenesis 21: 361-370.
25. Halliwell B (1999) Oxygen and nitrogen are pro-carcinogens. Damage to DNA by reactive oxygen, chlorine and nitrogen species: measurement, mechanism and the effects of nutrition. Mutat Res 443: 37-52.

26. Boyd NF, McGuire V (1991) The possible role of lipid peroxidation in breast cancer risk. Free Radic Biol Med 10: 185-190.

27. Xia C, Meng Q, Liu LZ, Rojanasakul Y, Wang XR, et al. (2007) Reactive oxygen species regulate angiogenesis and tumor growth through vascular endothelial growth factor. Cancer Res 67: 10823-10830.

28. Jo M, Nishikawa T, Nakajima T, Okada Y, Yamaguchi K, et al. (2011) Oxidative stress is closely associated with tumor angiogenesis of hepatocellular carcinoma. J Gastroenterol 46: 809-821.

29. Gorrini C, Harris IS, Mak TW (2013) Modulation of oxidative stress as an anticancer strategy. Nat Rev Drug Discov 12: 931-947.

30. Bahorun T, Soobrattee MA, Luximon-Ramma V, Aruoma OI (2006) Free radicals and antioxidants in cardiovascular health and disease. Internet $\mathrm{J}$. Med. Update 1: 1-17

31. Dröge W (2002) Free radicals in the physiological control of cell function. Physiol Rev 82: 47-95.

32. Chatterjee M, Saluja R, Kanneganti S, Chinta S, Dikshit M (2007) Biochemical and molecular evaluation of neutrophil NOS in spontaneously hypertensive rats. Cell Mol Biol (Noisy-le-grand) 53: 84-93.

33. Ceriello A (2008) Possible role of oxidative stress in the pathogenesis of hypertension. Diabetes Care 31 Suppl 2: S181-184.

34. Csányi G, Yao M, Rodríguez AI, Al Ghouleh I, Sharifi-Sanjani M, et al. (2012) Thrombospondin-1 regulates blood flow via CD47 receptormediated activation of NADPH oxidase 1. Arterioscler Thromb Vasc Biol 32: 2966-2973

35. Csányi G, Miller FJ Jr2 (2014) Oxidative stress in cardiovascular disease. Int J Mol Sci 15: 6002-6008.

36. Hess ML, Krause S, Kontos HA (1983) Mediation of sarcoplasmic reticulum disruption in the ischemic myocardium: proposed mechanism by the interaction of hydrogen ions and oxygen free radicals. Adv Exp Med Biol 161: 377-389.

37. Emerit J, Edeas M, Bricaire F (2004) Neurodegenerative diseases and oxidative stress. Biomed Pharmacother 58: 39-46.

38. Gandhi S, Abramov AY (2012) Mechanism of oxidative stress in neurodegeneration. Oxid Med Cell Longev 2012: 428010.

39. Butterfield DA (2002) Amyloid beta-peptide (1-42)-induced oxidative stress and neurotoxicity: implications for neurodegeneration in Alzheimer's disease brain. A review. Free Radic Res 36: 1307-1313.

40. Lovell MA, Ehmann WD, Butler SM, Markesbery WR (1995) Elevated thiobarbituric acid-reactive substances and antioxidant enzyme activity in the brain in Alzheimer's disease. Neurology 45: 1594-1601.

41. Xiang W, Schlachetzki JC, Helling S, Bussmann JC, Berlinghof M, et al. (2013) Oxidative stress-induced posttranslational modifications of alphasynuclein: specific modification of alpha-synuclein by 4-hydroxy-2nonenal increases dopaminergic toxicity. Mol Cell Neurosci 54: 71-83.

42. Zhou M, Xu S, Mi J, Uéda K, Chan P (2013) Nuclear translocation of alpha-synuclein increases susceptibility of MES23.5 cells to oxidative stress. Brain Res 1500: 19-27.

43. Dexter DT, Holley AE, Flitter WD, Slater TF, Wells FR, et al. (1994) Increased levels of lipid hydroperoxides in the parkinsonian substantia nigra: an HPLC and ESR study. Mov Disord 9: 92-97.

44. Alam ZI, Daniel SE, Lees AJ, Marsden DC, Jenner P, et al. (1997) A generalised increase in protein carbonyls in the brain in Parkinson's but not incidental Lewy body disease. J Neurochem 69: 1326-1329.

45. Alam ZI, Jenner A, Daniel SE, Lees AJ, Cairns N, et al. (1997) Oxidative DNA damage in the parkinsonian brain: an apparent selective increase in 8-hydroxyguanine levels in substantia nigra. J Neurochem 69: 1196-1203.

46. De Vos KJ, Grierson AJ, Ackerley S, Miller CC (2008) Role of axonal transport in neurodegenerative diseases. Annu Rev Neurosci 31: 151-173.

47. Jha NK, Jha SK, Kar R, Ambasta RK, Kumar P (2014) Role of Oxidative Stress, ER Stress and Ubiquitin Proteasome System in Neurodegeneration. MOJ Cell Sci Report 1: 00010. 
48. Deng HX, Chen W, Hong ST, Boycott KM, Gorrie GH, et al. (2011) Mutations in UBQLN2 cause dominant X-linked juvenile and adultonset ALS and ALS/dementia. Nature 477: 211-215.

49. Strong MJ (2010) The evidence for altered RNA metabolism in amyotrophic lateral sclerosis (ALS). J Neurol Sci 288: 1-12.

50. Kikuchi S, Shinpo K, Ogata A, Tsuji S, Takeuchi M, et al. (2002) Detection of $\mathrm{N}$ epsilon-(carboxymethyl)lysine (CML) and non-CML advanced glycation end-products in the anterior horn of amyotrophic lateral sclerosis spinal cord. Amyotroph Lateral Scler Other Motor Neuron Disord 3: 63-68.

51. Kim SJ, Jeong HJ, Myung NY, Kim MC, Lee JH, et al. (2008) The protective mechanism of antioxidants in cadmium-induced ototoxicity in vitro and in vivo. Environ Health Perspect 116: 854-862.

52. Hayes KC (1974) Retinal degeneration in monkeys induced by deficiencies of vitamin E or A. Invest Ophthalmol 13: 499-510.

53. Katz ML, Parker KR, Handelman GJ, Bramel TL, Dratz EA (1982) Effects of antioxidant nutrient deficiency on the retina and retinal pigment epithelium of albino rats: a light and electron microscopic study. Exp Eye Res 34: 339-369.

54. Mayne ST (2003) Antioxidant nutrients and chronic disease: use of biomarkers of exposure and oxidative stress status in epidemiologic research. J Nutr 133 Suppl 3: 933S-940S

55. Benzie IF, Strain JJ (1996) The ferric reducing ability of plasma (FRAP) as a measure of "antioxidant power": the FRAP assay. Anal Biochem 239 70-76.

56. Mohanty JG, Bhamidipaty S, Evans MK, Rifkind JM (2010) A fluorimetric semi-microplate format assay of protein carbonyls in blood plasma. Anal Biochem 400: 289-294.

57. Ohkawa H, Ohishi N, Yagi K (1979) Assay for lipid peroxides in animal tissues by thiobarbituric acid reaction. Anal Biochem 95: 351-358.

58. Collins CE, Quaggiotto P, Wood L, O'Loughlin EV, Henry RL, et al. (1999) Elevated plasma levels of F2 alpha isoprostane in cystic fibrosis. Lipids 34: 551-556.

59. ROE JH, MILLS MB, et al (1948) The determination of kiketo-1-gulonic acid, dehydro-1-ascorbic acid, and 1-ascorbic acid in the same tissue extract by the 2,4-dinitrophenylhydrazine method. J Biol Chem 174: 201-208.

60. Teissier E, Walters-Laporte E, Duhem C, Luc G, Fruchart JC, et al. (1996) Rapid quantification of alpha-tocopherol in plasma and low- and highdensity lipoproteins. Clin Chem 42: 430-435.

61. Misra HP, Fridovich I (1972) The role of superoxide anion in the autoxidation of epinephrine and a simple assay for superoxide dismutase. J Biol Chem 247: 3170-3175.

62. Aebi M (1974) Catalase. In: Bergmeyer HU, ed. Methods of enzymatic analysis. New York: Verlag Chemie-Academic Press (2): 673-684.

63. Flohe L, Gunzler WA (1984) Assays of glutathione peroxidase. In: Colowick SP, Kaplan NO, editors, Methods in enzymology. 12th ed. Orlando, Florida: Academic Press (105): 114-21.

64. Hissin PJ, Hilf R (1976) A fluorometric method for determination of oxidized and reduced glutathione in tissues. Anal Biochem 74: 214-226.
65. Haining JL, Legan JS (1967) Fluorometric assay for xanthine oxidase. Anal Biochem 21: 337-343.

66. Nauseef WM (2008) Biological roles for the NOX family NADPH oxidases. J Biol Chem 283: 16961-16965.

67. Burger D, Touyz RM (2012) Cellular biomarkers of endothelial health: microparticles, endothelial progenitor cells, and circulating endothelial cells. J Am Soc Hypertens 6: 85-99.

68. Touyz RM (2003) Reactive oxygen species in vascular biology: role in arterial hypertension. Expert Rev Cardiovasc Ther 1: 91-106.

69. Sinha MK, Gaze DC, Tippins JR, Collinson PO, Kaski JC (2003) Ischemia modified albumin is a sensitive marker of myocardial ischemia after percutaneous coronary intervention. Circulation 107(19): 2403-2405.

70. Comhair SA, Erzurum SC (2002) Antioxidant responses to oxidantmediated lung diseases. Am J Physiol Lung Cell Mol Physiol 283: L246-255.

71. Barnham KJ, Masters CL, Bush AI (2004) Neurodegenerative diseases and oxidative stress. Nat Rev Drug Discov 3: 205-214.

72. Wood LG1, Gibson PG, Garg ML (2003) Biomarkers of lipid peroxidation, airway inflammation and asthma. Eur Respir J 21: 177-186.

73. Montine TJ, Montine KS, McMahan W, Markesbery WR, Quinn JF, et al. (2005) F2-isoprostanes in Alzheimer and other neurodegenerative diseases. Antioxid Redox Signal 7: 269-275.

74. Montuschi P, Barnes PJ, Roberts LJ 2nd (2004) Isoprostanes: markers and mediators of oxidative stress. FASEB J 18: 1791-1800.

75. Butterfield DA, Castegna A (2003) Proteomics for the identification of specifically oxidized proteins in brain: technology and application to the study of neurodegenerative disorders. Amino Acids 25: 419-425.

76. Dalle-Donne I, Giustarini D, Colombo R, Rossi R, Milzani A (2003) Protein carbonylation in human diseases. Trends Mol Med 9: 169-176.

77. Pastore A, Federici G, Bertini E, Piemonte F (2003) Analysis of glutathione: implication in redox and detoxification. Clin Chim Acta 333: 19-39.

78. Bharath S, Hsu M, Kaur D, Rajagopalan S, Andersen JK (2002) Glutathione, iron and Parkinson's disease. Biochem Pharmacol 64: 1037-1048.

79. Lin CP, Lin FY, Huang PH, Chen YL, Chen WC, et al. (2013) Endothelial progenitor cell dysfunction in cardiovascular diseases: role of reactive oxygen species and inflammation. Biomed Res Int 2013: 845037.

80. Neeti S, Ajinkya AS, Ashwin VW (2014) Polyphenol composition and in vitroantioxidant activity of Prunus Amygdalus as affected by sprouting. Asian Journal of Agriculture and Food Sciences 2: 349-353.

81. Chetram MA, Bethea DA, Odero-Marah VA, Don-Salu-Hewage AS, Jones KJ, et al. (2013) ROS-mediated activation of AKT induces apoptosis via pVHL in prostate cancer cells. Mol Cell Biochem 376: 63-71.

82. Yan LJ (2014) Positive oxidative stress in aging and aging-related disease tolerance. Redox Biology 2: 165-169 